\title{
RESPONSE OF GRAIN SORGHUM (SORGHUM BICOLOR, L. MONECH) TO IRRIGATION, NITROGEN AND PLANT DENSITY UNDER NEW VALLEY CONDITIONS, EGYPT
}

\author{
Salem, Emad M.M. \\ Plant Production Department, Desert Research Center, 1 Mathaf El- \\ Matareya St., El-Matareya 11753, Cairo, Egypt. \\ E-mail: emadmms@yahoo.com
}
7 he proper agronomical practices should be carefully chosen for optimizing grain sorghum productivity, particularly under limited-resources environments. Therefore, two field experiments were carried out in the Desert Research Center, Agriculture Experimental Station at El-Kharga Oasis, New Valley Governorate, during 2010 and 2011 growing seasons, to evaluate the effect of irrigation rate $(5,6$ and $7 \mathrm{~mm} / \mathrm{fed} / \mathrm{day})$; nitrogen fertilization rate $(60,80$ and $100 \mathrm{~kg} \mathrm{~N} / \mathrm{fed})$ and plant density (17500, 23333 and 35000 plant/fed) on grain sorghum. Results showed that irrigation by $7 \mathrm{~mm} / \mathrm{fed} / \mathrm{day}$ was the potent treatment for increasing plant height, head length, head weight, weight of grains per head, seed index, grain yield, straw yield and biological yield compared to irrigation by 6 and $5 \mathrm{~mm} / \mathrm{fed} /$ day. On the contrary, water use efficiency (WUE) and protein percentage were significantly decreased with increasing irrigation levels in both seasons. Adding $100 \mathrm{~kg} \mathrm{~N} / \mathrm{fed}$ gave the maximum values of yield, yield components, water use efficiency and protein percentage compared to 80 and 60 $\mathrm{kg} \mathrm{N} / \mathrm{fed}$ in both seasons. Increasing plant density from 17500 to 35000 plant/fed caused significant increases in yield, yield attributes, water use efficiency and protein percentage, except for head weight, weight of grains per head and seed index in both seasons. Plots irrigated by $7 \mathrm{~mm} / \mathrm{fed}$ and fertilized with $100 \mathrm{~kg}$ $\mathrm{N} / \mathrm{fed}$ achieved the maximum values of grain, straw and biological yield/fed, when sorghum plants grown at high density (35000 plant/fed).

Keywords: grain sorghum, irrigation levels, $\mathrm{N}$ rates, plant density, WUE

New Valley region (located at the Western Desert of Egypt) is considered one of the promising locations by its oases for agricultural expansion; it represents $45 \%$ of Egypt area. Its weather is hot-dry and cultivation depends mainly on ground water, so sustainable agriculture 
requires application of quixotic cultural management for better use of land and water resources.

Grain sorghum as a staple food grain in several developing countries (Buah and Mwinkaara, 2009) is an important crop in arid and semiarid regions, because of its environmental adaptability. Also, sorghum is one of the most widely adapted forage crops to the arid and semi-arid tropics and dry-temperate areas of the world (Kidambi et al., 1990 and Blum, 2004). The productivity of grain sorghum could be increased by improving the cultural practices, such as irrigation regime, nitrogen fertilizer and plant density.

Irrigation water is a limiting factor in newly reclaimed areas as New Valley, due to the shortage in water resources, which causes serious crop damages. Therefore, there is a dire need to determine the optimum water requirement in order to reach the highest crop production with water rationalization. Availability of adequate amount of moisture at the critical stages of plant growth not only optimizes the metabolic process in plant cell, but also increases the effectiveness of the mineral nutrients applied to the crop, consequently any degree of water stress may produce deleterious effects on growth and yield of the crop. Previous studies on sorghum have shown that total leaf area and specific leaf area decreased under water stress, while, the root to shoot ratio increased (Munamava and Riddoch, 2001). A significant improvement in plant and dry matter formation measured as grain and straw yields was recorded with the increasing levels of irrigation (AbdelMotagally, 2010). Afshar et al. (2014) stated that deficit irrigation reduced grain yield while, improving irrigation water use efficiency (WUE). Sher et al. (2013) noticed that the biomass traits and WUE were more influenced by water regimes, and similar trend was obtained by Fernandez et al. (2012).

On the other side, nitrogen is the key limiting factor and essential macronutrient required for most crops. Nitrogen is the most expensive fertilizer used to raise crop plants yield (Spiertz, 2010). However, sufficient or insufficient fertilization lead to economic losses and discharge an excessive amount of nitrogen in the nitrate from through washing (Henke et al., 2007). Asghari et al. (2006) reported that the increase in fertilization rate from 0 to $150 \mathrm{~kg} / \mathrm{ha}$ increased significantly grain yield. Moreover, studies have shown that grain yield significantly differed at different nitrogen levels and grain yield increased at more nitrogen application rates (Mousavi et al., 2012; Zand and Shakiba, 2013; Abou-Amer and Kewan, 2014; Mahama et al., 2014 and Zand et al., 2014).

It is worth noticing that determining the optimal plant density that achieves the minimal intra-specific competition is essential to maximize the usage of water and nutrients per land unit area resulting in increasing productivity and more economical return under these conditions. In this connection, combined use of fertilizer and optimum plant density may increase food production and safe guard the environment for future Egyptian J. Desert Res., 65, No. 1, 11-30 (2015) 
generation (Buah and Mwinkaara, 2009). Reducing the distance between rows can also improve weed control by increasing crop competitiveness and reducing light transmittance to the soil (Andrade et al., 2002). Also, weedgrain sorghum competition is intensified by open canopy structures (Everaarts, 1993), while narrow row planting gives grain sorghum a competitive advantage over weeds (Walker and Buchanan, 1982). Javadi et al. (2005) noticed that higher plant density resulted in higher grain yield and biological yield. They stated that the increase in the density from 100000 to 260000 plants/ha resulted in 37.26 and $41.41 \%$ increase in grain and biological yield, respectively. Previous researches have indicated that grain yields generally increase as plant populations increase (Soleymani et al., 2011; Fernandez et al., 2012; Mousavi et al., 2012 and Zand and Shakiba, 2013).

In view of the above mentioned results, the aim of the present study is to determine the most appropriate irrigation water amount, nitrogen fertilization rate and optimum plant density on grain sorghum productivity under New Valley region of Egypt.

\section{MATERIALS AND METHODS}

\section{Site Description}

A two-year field experiment was carried out in the Desert Research Center (DRC), Agricultural Experimental Station at El-Kharga Oasis, New Valley Governorate, Egypt, during the two summer growing seasons of 2010 and 2011. The soil of the site is sandy clay loam containing $2.08 \%$ organic matter, $\mathrm{pH}$ of 8.5 and $\mathrm{EC}$ of $4.5 \mathrm{dS} / \mathrm{m}$. The preceding crop was wheat in both seasons.

\section{Experimental Treatments and Design}

The study included three tested factors, i.e. irrigation, nitrogen and plant density. A split-split plot design with three replicates was used. Whereas, irrigation treatments were arranged in the main plots, nitrogen rates were distributed in the sub plots, and plant density patterns occupied the sub-sub plots. The experimental unit area was $10.5 \mathrm{~m}^{2}$ containing five ridges ( $3.5 \mathrm{~m}$ length and $60 \mathrm{~cm}$ apart).

\subsection{Irrigation treatments}

Three irrigation levels were applied through gated pipe irrigation system (5, 6 and $7 \mathrm{~mm} / \mathrm{fed} /$ day, which were equivalent to 2100,2520 and $2940 \mathrm{~m}^{3} / \mathrm{fed}$, respectively). Well water was the source of irrigation with $\mathrm{pH}$ of 7.4 and EC of $1.09 \mathrm{dS} / \mathrm{m}$, was used. Water amounts of irrigation levels were calculated based on evapotranspiration rate for each growth stage 
during each growing season. Irrigation water requirement for sorghum was calculated using the meteorological data at of the region as follows:

a. Crop evapotranspiration was calculated according to Doorenbos et al. (1977):

$$
\mathrm{ET}_{\mathrm{c}}=\mathrm{ET}_{\mathrm{o}} \times \mathrm{K}_{\mathrm{c}}
$$

Where:

$$
\begin{array}{ll}
\mathrm{ET}_{\mathrm{c}}= & \text { Crop evapotranspiration }(\mathrm{mm} / \text { day }), \\
\mathrm{ET}_{\mathrm{o}}= & \text { Reference evapotranspiration }(\mathrm{mm} / \text { day }), \\
\mathrm{K}_{\mathrm{c}}= & \text { Crop coefficient. }
\end{array}
$$

b. Applied irrigation water for sorghum crop was calculated according to Keller and Bliesner (1990):

Where:

$$
\begin{array}{ll}
\mathrm{IR}= & \text { Irrigation requirement }\left(\mathrm{m}^{3} / \mathrm{ha}\right), \\
\mathrm{LR}= & \text { Leaching requirement }(\%),(15 \%), \\
\mathrm{E}_{\mathrm{a}}= & \begin{array}{l}
\text { Water application WUE, }(80 \% \text { for gated } \\
\text { pipe system) } .
\end{array}
\end{array}
$$

\subsection{Nitrogen rates}

Nitrogen fertilizer at the rates of 60,80 and $100 \mathrm{~kg} \mathrm{~N} /$ fed were applied in the form of ammonium nitrate $(33.5 \% \mathrm{~N})$ in two equal portions. The first portion was added on the $21^{\text {st }}$ day after sowing, directly before thinning, and the second one on the $35^{\text {th }}$ day after sowing.

\subsection{Plant density patterns}

Three plant densities, i.e. 17500, 23333 and 35000 plant/fed could be realized by planting sorghum in hills in one side of the ridge and the distances between hills were 40,30 and $20 \mathrm{~cm}$, respectively.

A grain sorghum cultivar (Dorado) was grown in May 19 and 22 in the first and second seasons, respectively. Phosphorus fertilizer was applied in the form of calcium super phosphate $\left(15 \% \mathrm{P}_{2} \mathrm{O}_{5}\right)$ at a rate of $30 \mathrm{~kg}$ $\mathrm{P}_{2} \mathrm{O}_{5} /$ fed during soil preparation. On the $21^{\text {st }}$ day after sowing, plants were thinned to secure one plant per hill. Potassium fertilizer was applied in the form of potassium sulfate $\left(48 \% \mathrm{~K}_{2} \mathrm{O}\right)$ at a rate of $24 \mathrm{~kg} \mathrm{~K} 2 \mathrm{O} / \mathrm{fed}$ at the $70^{\text {th }}$ day after sowing. All other recommended agricultural practices were adopted throughout the two experimental seasons.

\section{Sampling and Assessments}

\subsection{Yield traits}

At harvest, ten guarded plants were taken randomly from each plot to measure plant height, head length, head weight, weight of grains/head and seed index. Moreover, whole plants of the plot were collected to measure grain, straw and biological yield/fed. 


\subsection{Grains nitrogen content}

Total nitrogen was determined in grains using the modified micro kjeldahl method as described in A.O.A.C. (1995). Crude protein content \% was calculated by multiplying the total nitrogen $\%$ by 6.25 .

\subsection{Water use efficiency (WUE)}

Water use efficiency was calculated to evaluate the treatments, which have given the maximum yield per unit of water applied in the field. Sorghum grains moisture content was adjusted to be about $15.5 \%$ and the WUE was expressed as grain sorghum yield $(\mathrm{kg}) /$ applied water $\left(\mathrm{m}^{3}\right)$, according to Pene and Edi (1996).

\section{Statistical Methods}

All the obtained data of each season were exposed to the proper statistical analysis of variance according to Gomez and Gomez (1984). Least significance difference (LSD) test at 0.05 level of significance was used for the comparison between means.

\section{RESULTS AND DISCUSSION}

Available results in table (1,2 and 3) explain that the main effect of each irrigation, $\mathrm{N}$ fertilization and plant density had marked impact on all yield and its components, WUE and protein percentage of grain sorghum.

\section{Effect of Irrigation}

As shown in table (1), plant height, head length, head weight per plant, weight of grains per head, seed index, grain yield, straw yield and biological yield were significantly enhanced with increasing irrigation levels in both seasons, while WUE and protein percentage were decreased. The highest values of sorghum yield and its components were achieved with irrigation by $7 \mathrm{~mm} / \mathrm{fed} /$ day, whereas irrigation by $5 \mathrm{~mm} / \mathrm{fed} /$ day was the inferior treatment. In this regard, the increments in grain sorghum yield and its components due to increasing irrigation water might be attributed to the beneficial effect of irrigation on growth and photosynthetic capacity. Consequently, more dry matter accumulated in yield components, which reflected on grain and biological yield/fed, Moreover, increasing irrigation water amount enhances the ability of plants to effectively utilize the environmental resources. This in turns increases the amount of metabolites synthesized (by plant). Water is generally considered as one of the limiting factors, which affects the physiological and biochemical processes influencing crop productivity. Moreover, water provides turgidity to the cell while water stress causes dehydration reducing the enlargement and 


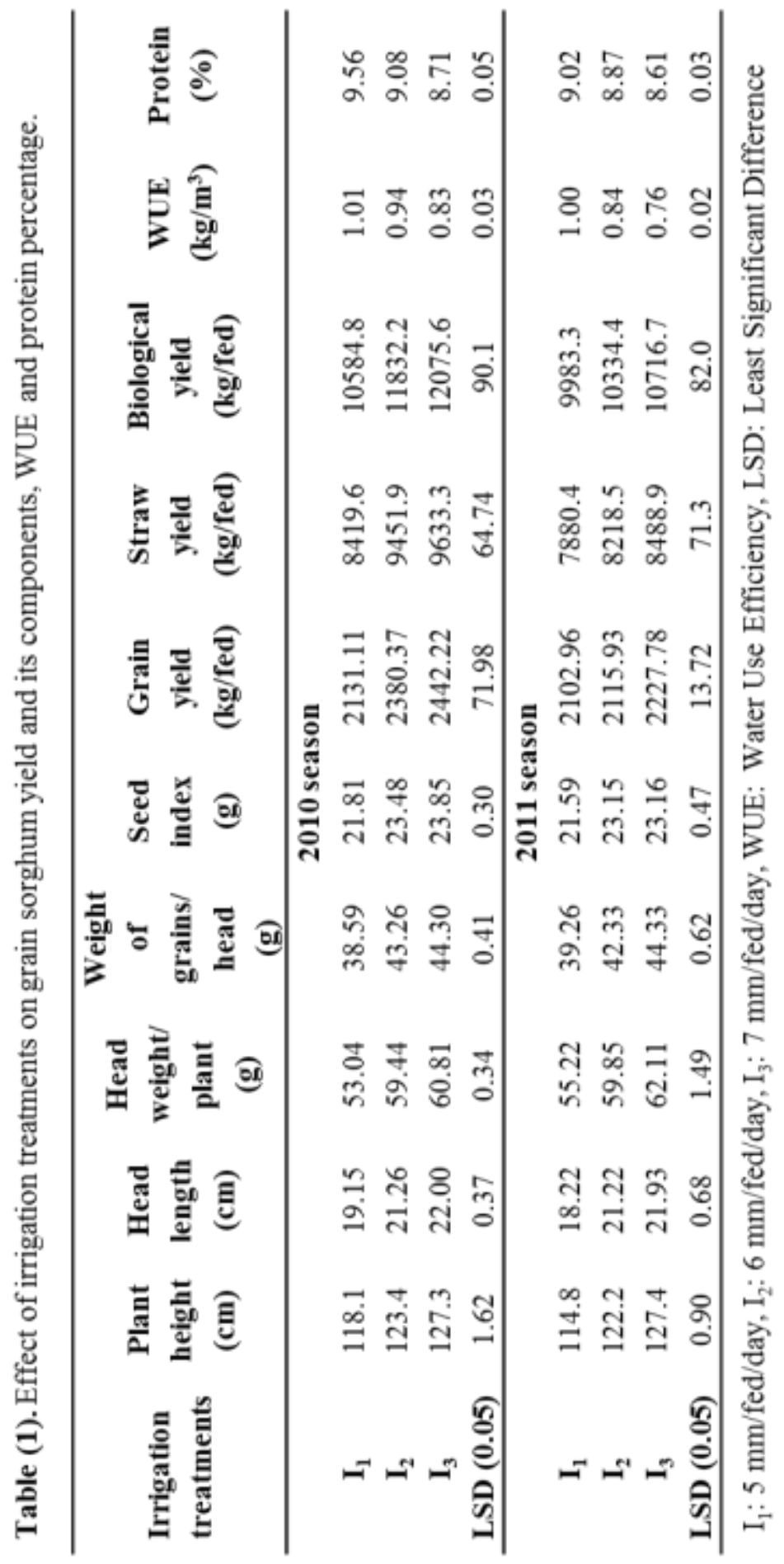

Egyptian J. Desert Res., 65, No. 1, 11-30 (2015) 
expansion of the cell, resulting in a reduction in leaf area. The reduction in leaf area certainly affects the overall growth of the crop (Swati et al., 1985). These results are in harmony with those of Munamava and Riddoch (2001), El-Sarag and Abu Hashem (2009), Abdel-Motagally (2010), Beheshti and Fard (2010), Jahanzad et al. (2013) and Afshar et al. (2014). Regarding WUE and protein percentage, irrigation by $5 \mathrm{~mm} / \mathrm{fed} /$ day gave the highest significant values in both seasons (Table 1). While the lowest values were obtained at irrigation treatment by $7 \mathrm{~mm} / \mathrm{fed} /$ day. Large quantity of irrigation water applied with the treatment of $7 \mathrm{~mm} / \mathrm{fed} /$ day may cause reduction in WUE than adding $5 \mathrm{~mm} / \mathrm{fed} /$ day. These results are in agreement with those stated by Abdalla et al. (1994), Mastrorilli et al. (1995), Abdel-Motagally (2010) and Afshar et al. (2014).

\section{Effect of Nitrogen Fertilizer}

Data of 2010 and 2011 seasons presented in table (2) clearly showed that abundant supply of nitrogen fertilizer markedly enhanced all studied traits. Adding $100 \mathrm{~kg} \mathrm{~N} / \mathrm{fed}$ recorded the maximum values of yield and yield components, WUE and protein percentage. Such efficient treatment increased plant height, head length, head weight/plant, weight of grains/head, seed index, grain yield, straw yield, biological yield as well as WUE and protein percentage by 5.9, 4.6, 4.8, 5.0, 9.8, 9.8, 8.6, 8.5, 9.1 and $5.8 \%$, respectively, in the first season and by $3.6,4.3,10.3,6.6,4.0,9.9$, $12.2,11.4,9.8$ and $5.5 \%$, respectively, in the second one, compared to adding $60 \mathrm{~kg} \mathrm{~N} / \mathrm{fed}$. The increments in yield and yield components as well as WUE and protein percentage by increasing nitrogen levels may be due to the fact that nitrogen fertilizer increased vegetative growth, leaf area and photosynthesis capacity whereby the grain sorghum plants efficiently used solar radiation for dry matter production. Additionally, nitrogen fertilization resulted in the increase in grain number per panicle and 1000-grain weight, which may be due to the increase in the fertile flowers and more appropriate nutritional conditions for grains during grain filling period by providing suitable conditions for plant cover formation, which reflected on grain yield and biomass/plant, and consequently increase yield and yield attributes. The obtained results are in agreement with those of and Asghari et al. (2006), Soleymani et al. (2011), Mousavi et al. (2012), Abou-Amer and Kewan (2014), Mahama et al. (2014) and Zand et al. (2014).

\section{Effect of Plant Density}

Planting 35000 plant/fed caused increments in all studied traits, except for head weight per plant, weight of grains/head and seed index in both seasons (Table 3). Such potent pattern increased each of plant height, 


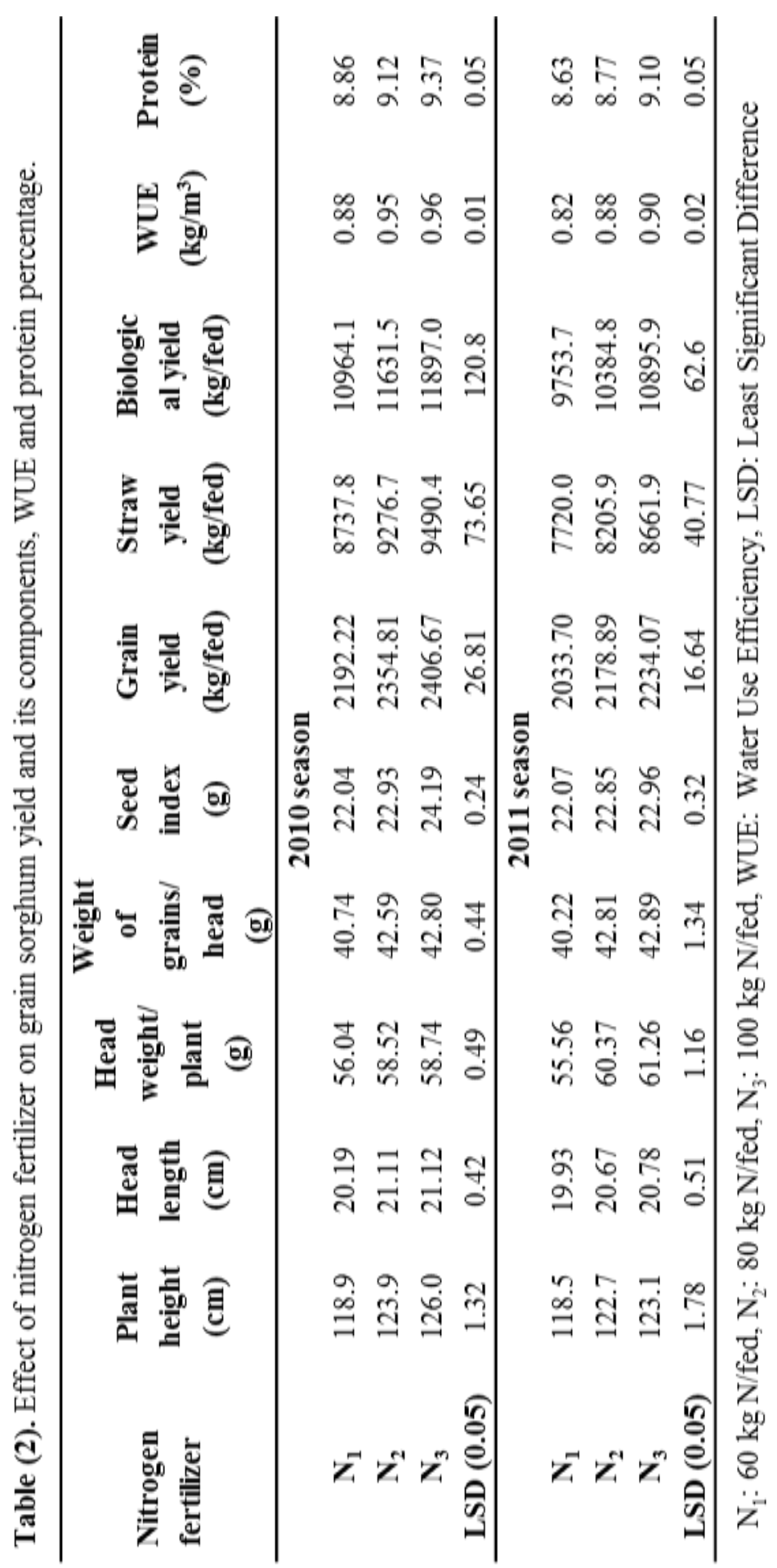

Egyptian J. Desert Res., 65, No. 1, 11-30 (2015) 


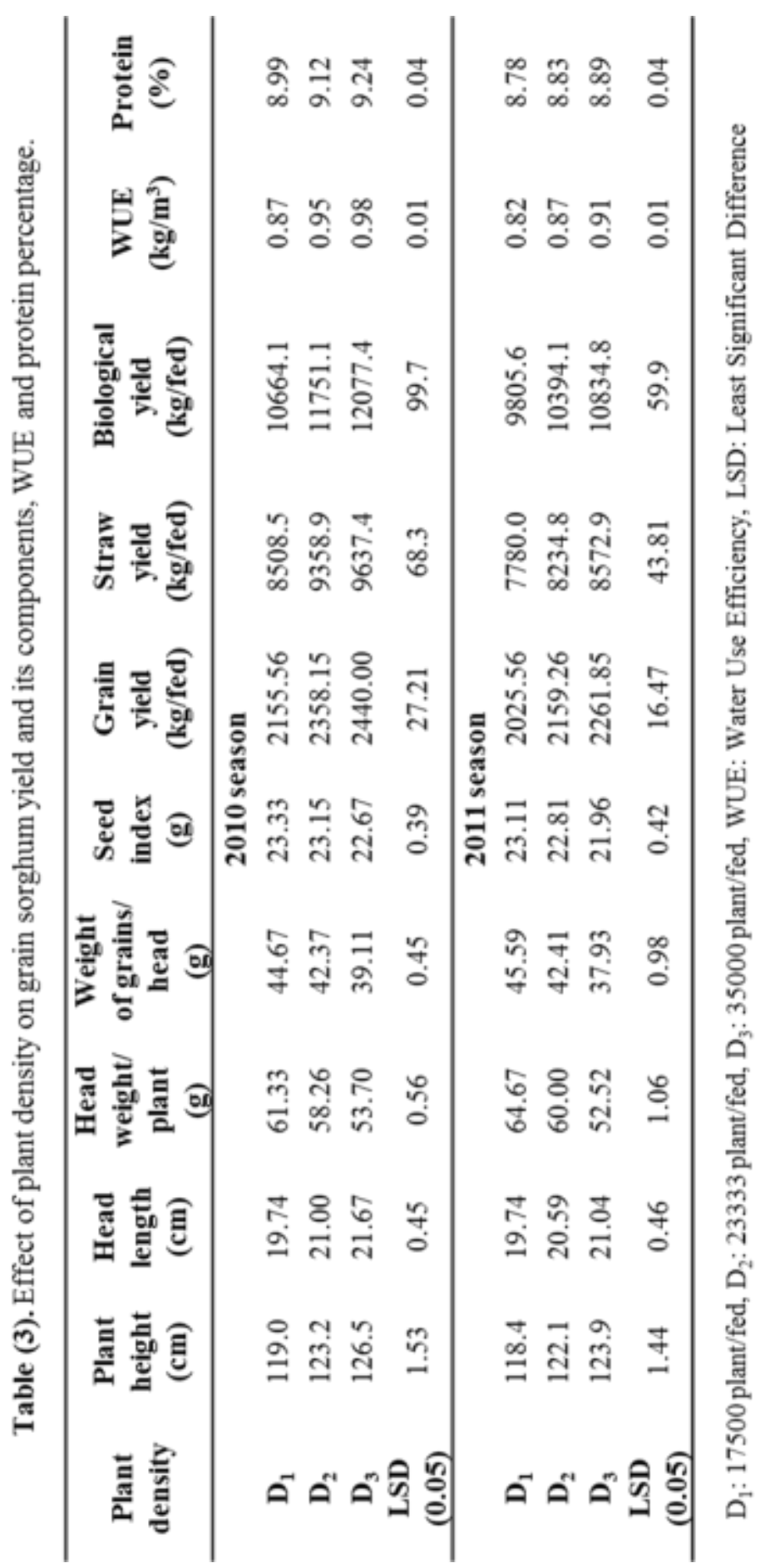

Egyptian J. Desert Res., 65, No. 1, 11-30 (2015) 
head length, grain yield, straw yield and biological yield as well as WUE and protein percentage by $6.3,9.8,13.2,13.3,13.3,12.6$ and $2.8 \%$ in the first season and 4.7, 6.6, 11.7, 10.2, 10.5, 11.0 and $1.3 \%$ in the second one, respectively, as compared with the pattern of 17500 plant/fed. These enhancements might be due to that the high density under 35000 plant/fed patterns would allow more efficient available sunlight, moisture and nutrients, besides it saved the maximum number of harvested plants/unit area. It has been reported that the yield response to narrow rows in grain sorghum is affected by many environmental, spatial and temporal field interactions (Andrade et al., 2002 and Thelen, 2006). These results are in harmony with those obtained by Javadi et al. (2005), Lak et al. (2006), Soleymani et al. (2011), Fernandez et al. (2012), Mousavi et al. (2012) and Zand et al. (2014).

Contrariwise, planting 17500 plant/fed increased head weight by 14.2 and $23.1 \%$, weight of grains/head by 14.2 and $20.2 \%$ and seed index by 2.9 and $5.2 \%$, in the first and second seasons, respectively, compared with 35000 plant/fed treatment. These results are supported by findings of Mousavi et al. (2012) and Zand et al. (2014). The superiority of 17500 plant/fed treatment in head weight, weight of grains/head and seed index may be due to low intra-specific competition among grain sorghum plants under low plant population in turn enhancing the most plant growth traits consequently. This enables plants to make good use of the environmental resources as water and nutrients, which is reflected on yield components.

\section{Effect of Interactions}

First order interactions, i.e. irrigation $\times$ nitrogen; irrigation $\times$ plant density and nitrogen $\times$ plant density are presented in table 4,5 and 6 as well as the second order interaction, i.e. irrigation $\times$ nitrogen $\times$ plant density is shown in table 7 and 8 .

\subsection{Irrigation $\times$ nitrogen}

Data in table (4) show the impact of the interaction between irrigation levels and nitrogen treatments on yield and its components as well as, WUE and protein percentage in both seasons. The combination of irrigation by 7 $\mathrm{mm} / \mathrm{fed} /$ day with adding $100 \mathrm{~kg} \mathrm{~N} / \mathrm{fed}$ gave the highest values of plant height, head length and weight, weight of grains/head, seed index, grain yield, straw yield and biological yield in both seasons. While, the combination of irrigation by $5 \mathrm{~mm} / \mathrm{fed} /$ day with adding $80 \mathrm{~kg} \mathrm{~N} / \mathrm{fed}$ recorded the maximum values of WUE in both seasons. Also, the same irrigation treatment with adding $100 \mathrm{~kg} \mathrm{~N} / \mathrm{fed}$ was the best treatment for improving protein percentage in both seasons.

\subsection{Irrigation $\times$ plant density}

With exception of weight of grains/head and seed index, considerable effect of the interaction between irrigation levels $\times$ plant Egyptian J. Desert Res., 65, No. 1, 11-30 (2015) 
density on all yield and yield traits as well as WUE and protein percentage were obtained (Table 5). In this concern, irrigation by $7 \mathrm{~mm} / \mathrm{fed} /$ day with plant density of 35000 plant/fed recorded the maximum values for plant height, head length, grain yield, straw yield and biological yield in both seasons. Additionally, irrigation by $7 \mathrm{~mm} / \mathrm{fed}$ with plant density of 17500 plant/fed was the superior combination for promoting head weight in both seasons. Moreover, irrigation by $5 \mathrm{~mm} / \mathrm{fed} /$ day with plant density of 35000 plant/fed secured the maximum WUE and protein percentage in both seasons. These results are in similar trend with those of Steiner (1986) and Sanabria et al. (1995).

\subsection{Nitrogen $\times$ plant density}

The interaction between nitrogen fertilizer and plant density treatment showed a remarkable effect on grain, straw and biological yield/fed. Whereas, no significant differences were obtained in plant height, head length, seed index and protein percentage in both seasons (Table 6). Herein, the effective combination was nitrogen fertilizer at $100 \mathrm{~kg} \mathrm{~N} / \mathrm{fed}$ with plant density of 35000 plant/fed for increasing grain, straw and biological yield/fed. Moreover, combination of adding $100 \mathrm{~kg} \mathrm{~N} / \mathrm{fed}$ with plant density of 17500 plant/fed recorded the maximum values of head weight/plant and weight of grains/head in the first season. Also, adding 80 $\mathrm{kg} \mathrm{N} / \mathrm{fed}$ with plant density of 35000 plant/fed was the most effective for enhancing WUE in the first season. These results are in harmony with those obtained by Zand and Shakiba (2013) and Zand et al. (2014).

\subsection{Irrigation $\times$ nitrogen $\times$ plant density}

Head weight/plant and grain, straw and biological yield/fed were significantly affected by second order interaction (among irrigation levels, nitrogen fertilizer and plant density). While, plant height has not been affected in both seasons (Table 7 and 8). Therein, in the first season, plots irrigated by $7 \mathrm{~mm} / \mathrm{fed} / \mathrm{day}$ and $100 \mathrm{~kg}$ nitrogen recorded the highest values of head weight, seed index, grain, straw and biological yield/fed when grain sorghum plants were planted at high density (35000 plant/fed). In the second season, irrigation by $7 \mathrm{~mm} / \mathrm{fed} /$ day $\mathrm{x} 100$ $\mathrm{kg}$ nitrogen $\times 35000$ plant/fed showed the maximum values of grain, straw and biological yield/fed. While, the heaviest head was gained from irrigation by $7 \mathrm{~mm} / \mathrm{fed} /$ day x $100 \mathrm{~kg}$ nitrogen x $17500 \mathrm{plant} / \mathrm{fed}$. Moreover, the effective combinations for improving WUE and protein percentage were possessed with irrigation by $5 \mathrm{~mm} / \mathrm{fed} \times 80 \mathrm{~kg} \mathrm{~N} / \mathrm{fed} \times$ plant density of 17000 plant/fed and irrigation by $5 \mathrm{~mm} / \mathrm{fed} \times 100 \mathrm{~kg} \mathrm{~N} / \mathrm{fed} \times$ plant density of $35000 \mathrm{plant} / \mathrm{fed}$, respectively, in the first season only. 


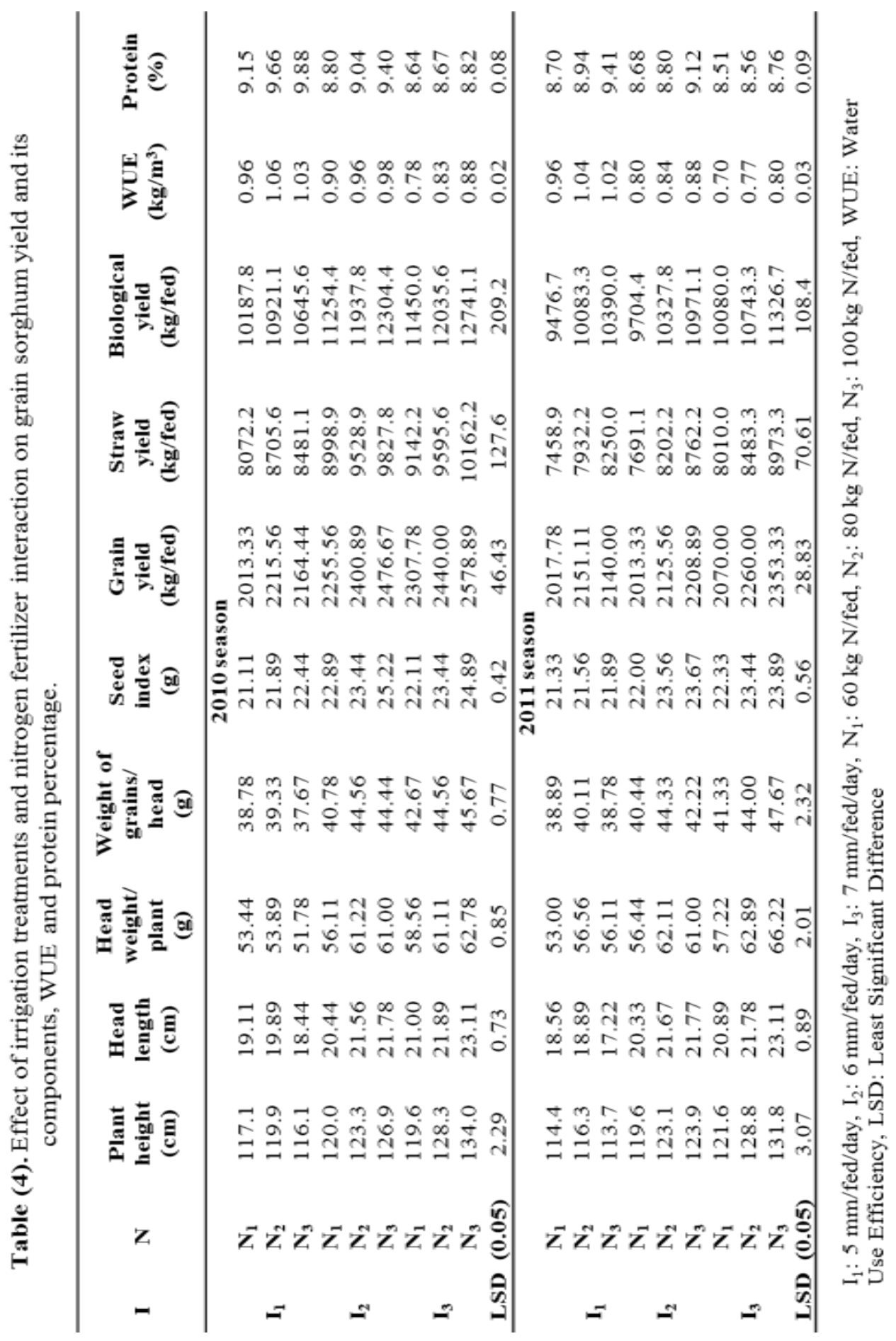

Egyptian J. Desert Res., 65, No. 1, 11-30 (2015) 


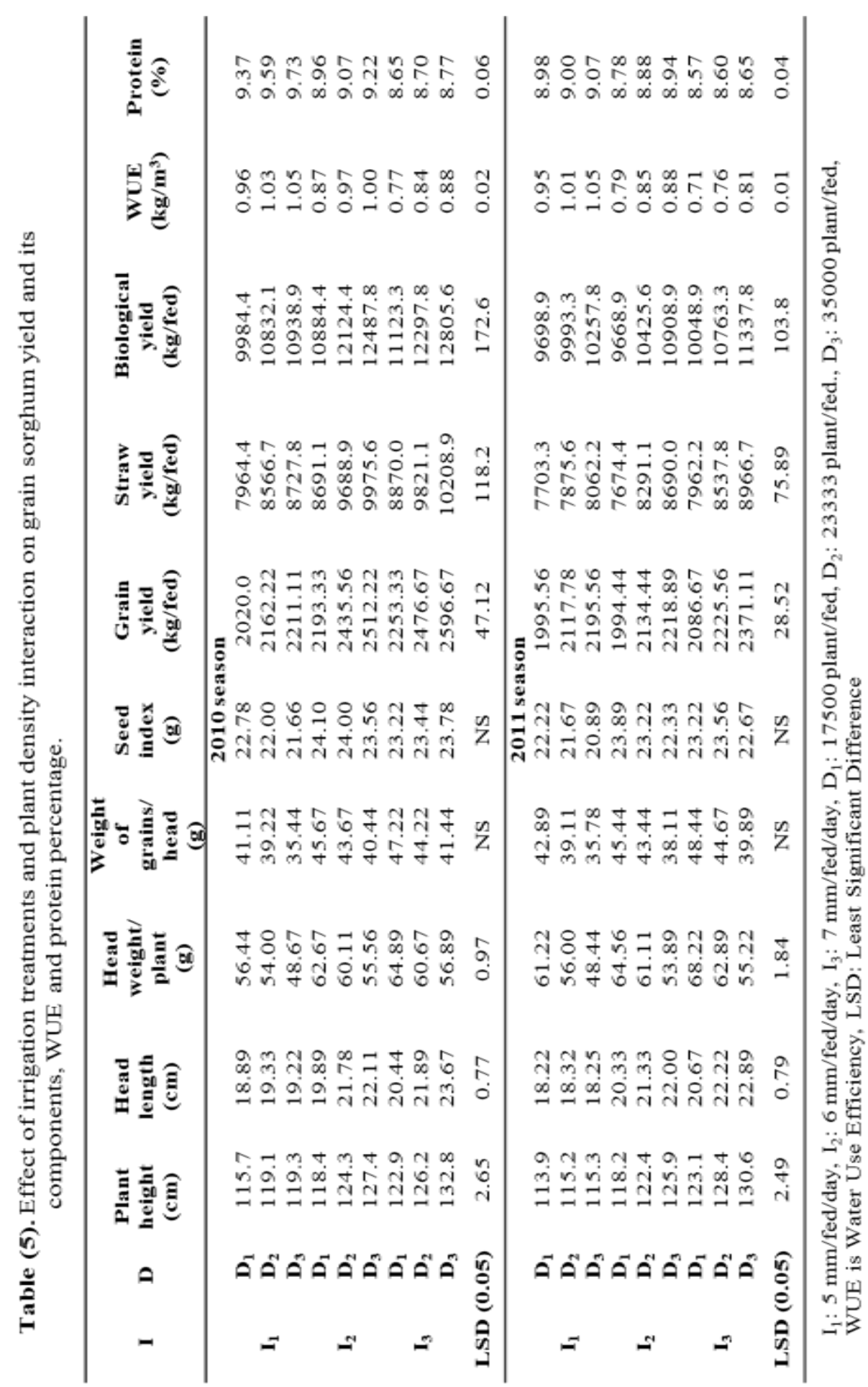

Egyptian J. Desert Res., 65, No. 1, 11-30 (2015) 
Table (6). Effect of nitrogen fertilizer and plant density interaction on grain sorghum yield and its components, WUE and protein percentage.

\begin{tabular}{|c|c|c|c|c|c|c|c|c|c|c|c|}
\hline $\mathrm{N}$ & D & $\begin{array}{c}\text { Plant } \\
\text { height } \\
(\mathrm{cm})\end{array}$ & $\begin{array}{l}\text { Head } \\
\text { length } \\
(\mathrm{cm})\end{array}$ & $\begin{array}{c}\text { Head } \\
\text { weight/ } \\
\text { plant } \\
\text { (g) } \\
\end{array}$ & $\begin{array}{c}\text { Weight } \\
\text { of } \\
\text { grains/ } \\
\text { head } \\
\text { (g) }\end{array}$ & $\begin{array}{l}\text { Seed index } \\
\text { (g) }\end{array}$ & $\begin{array}{c}\text { Grain } \\
\text { yield } \\
\text { (kg/fed) }\end{array}$ & $\begin{array}{c}\text { Straw } \\
\text { yield } \\
\text { (kgffed) }\end{array}$ & $\begin{array}{c}\text { Biological } \\
\text { yield } \\
\text { (kg/fed) }\end{array}$ & $\begin{array}{c}\text { WUE } \\
\left(\mathrm{kg} / \mathrm{m}^{3}\right)\end{array}$ & $\begin{array}{c}\text { Protein } \\
(\%)\end{array}$ \\
\hline \multicolumn{12}{|c|}{2010 season } \\
\hline \multirow{4}{*}{$\mathrm{N}_{1}$} & $\mathbf{D}_{1}$ & 114.8 & 19.00 & 60.44 & 44.00 & 22.11 & 2015.56 & 8002.2 & 10017.8 & 0.81 & 8.73 \\
\hline & $\mathbf{D}_{2}$ & 119.3 & 20.22 & 57.00 & 41.33 & 22.33 & 2254.44 & 9016.7 & 11373.3 & 0.90 & 8.88 \\
\hline & $\mathbf{D}_{3}$ & 122.6 & 21.33 & 50.67 & 36.89 & 21.67 & 2306.67 & 9194.4 & 11501.1 & 0.92 & 8.97 \\
\hline & $\mathbf{D}_{1}$ & 119.7 & 20.11 & 61.67 & 44.89 & 23.44 & 2193.33 & 8625.6 & 10818.9 & 0.88 & 9.00 \\
\hline \multirow[t]{3}{*}{$\mathbf{N}_{2}$} & $\mathbf{D}_{2}$ & 123.6 & 21.44 & 59.33 & 43.22 & 22.78 & 2360.00 & 9375.6 & 11735.6 & 0.95 & 9.14 \\
\hline & $\mathbf{D}_{3}$ & 128.3 & 21.78 & 55.22 & 40.33 & 22.56 & 2502.22 & 9828.9 & 12331.1 & 1.01 & 9.23 \\
\hline & $\mathbf{D}_{1}$ & 122.6 & 20.11 & 61.89 & 45.11 & 24.44 & 2257.78 & 8897.8 & 11155.6 & 0.91 & 9.23 \\
\hline \multirow[t]{2}{*}{$\mathrm{N}_{3}$} & $\mathbf{D}_{2}$ & 126.8 & 21.33 & 58.44 & 42.56 & 24.33 & 2460.00 & 9684.4 & 12144.6 & 0.98 & 9.35 \\
\hline & $\mathbf{D}_{3}$ & 128.7 & 21.89 & 55.22 & 40.11 & 23.78 & 2511.11 & 9888.9 & 12400.1 & 1.00 & 9.52 \\
\hline \multicolumn{2}{|c|}{$\operatorname{LSD}(0.05)$} & NS & NS & 0.97 & 0.77 & NS & 47.12 & 118.2 & 172.6 & 0.02 & NS \\
\hline \multicolumn{12}{|c|}{2011 season } \\
\hline \multirow{3}{*}{$\mathrm{N}_{1}$} & $\mathbf{D}_{1}$ & 115.7 & 19.00 & 62.11 & 44.22 & 22.33 & 1922.22 & 7470.0 & 9392.2 & 0.78 & 8.59 \\
\hline & $\mathbf{D}_{2}$ & 119.1 & 20.00 & 56.67 & 40.67 & 22.44 & 2056.67 & 7707.8 & 9764.4 & 0.83 & 8.65 \\
\hline & $\mathbf{D}_{3}$ & 120.8 & 20.78 & 47.89 & 35.78 & 21.44 & 2122.22 & 7982.2 & 10104.4 & 0.86 & 8.64 \\
\hline \multirow{3}{*}{$\mathrm{N}_{2}$} & $\mathbf{D}_{1}$ & 120.2 & 19.89 & 65.67 & 45.78 & 23.11 & 2046.67 & 7774.4 & 9821.1 & 0.83 & 8.71 \\
\hline & $\mathbf{D}_{2}$ & 121.9 & 20.89 & 61.22 & 43.22 & 23.00 & 2181.11 & 8266.7 & 10447.8 & 0.88 & 8.72 \\
\hline & $\mathbf{D}_{3}$ & 126.1 & 21.56 & 54.22 & 39.44 & 22.44 & 2308.89 & 8576.7 & 10885.6 & 0.93 & 8.87 \\
\hline \multirow{4}{*}{$N_{3}$} & $\mathbf{D}_{1}$ & 119.3 & 20.33 & 66.22 & 46.78 & 23.89 & 2107.78 & 8095.6 & 10203.3 & 0.85 & 9.02 \\
\hline & $\mathbf{D}_{2}$ & 124.9 & 20.78 & 62.11 & 43.33 & 23.00 & 2240.00 & 8730.0 & 10970.0 & 0.90 & 9.10 \\
\hline & $\mathbf{D}_{3}$ & 125.1 & 20.89 & 55.44 & 38.56 & 22.00 & 2354.44 & 9160.0 & 11514.4 & 0.95 & 9.16 \\
\hline & $.05)$ & $\mathrm{NS}$ & NS & $\mathrm{NS}$ & NS & NS & 28.52 & 75.89 & 103.8 & NS & $\mathrm{NS}$ \\
\hline
\end{tabular}

$\mathrm{N}_{1}: 60 \mathrm{~kg} \mathrm{~N} /$ fed, $\mathrm{N}_{2}: 80 \mathrm{~kg} \mathrm{~N} / \mathrm{fed}, \mathrm{N}_{3}: 100 \mathrm{~kg} \mathrm{~N} / \mathrm{fed}, \mathrm{D}_{1}: 17500$ plant/fed, $\mathrm{D}_{2}: 23333$ plant/fed, $\mathrm{D}_{3}: 35000$ plant/fed, WUE: Water Use Efficiency, LSD: Least Significant Difference

Egyptian J. Desert Res., 65, No. 1, 11-30 (2015) 
Table (7). Effect of irrigation treatments, nitrogen fertilizer and plant density interaction on grain sorghum yield and its components, WUE and protein percentage (2010 season).

\begin{tabular}{|c|c|c|c|c|c|c|c|c|c|c|c|c|}
\hline I & $\mathbf{N}$ & D & $\begin{array}{c}\text { Plant } \\
\text { height } \\
(\mathrm{cm})\end{array}$ & $\begin{array}{c}\text { Head } \\
\text { length } \\
(\mathrm{cm})\end{array}$ & $\begin{array}{l}\text { Head } \\
\text { weight/ } \\
\text { plant } \\
\text { (g) }\end{array}$ & $\begin{array}{l}\text { Weight } \\
\text { of grains/ } \\
\text { head } \\
\text { (g) }\end{array}$ & $\begin{array}{l}\text { Seed index } \\
\text { (g) }\end{array}$ & $\begin{array}{c}\text { Grain yield } \\
(\mathrm{kg} / \mathrm{fed})\end{array}$ & $\begin{array}{c}\text { Straw yield } \\
(\mathrm{kg} / \mathrm{fed})\end{array}$ & $\begin{array}{l}\text { Biological } \\
\text { yield } \\
(\mathrm{kg} / \mathrm{fed})\end{array}$ & $\begin{array}{c}\text { WUE } \\
\left(\mathrm{kg} / \mathrm{m}^{3}\right)\end{array}$ & $\begin{array}{c}\text { Protein } \\
(\%)\end{array}$ \\
\hline \multirow{10}{*}{$\mathbf{I}_{1}$} & \multirow{3}{*}{$\mathrm{N}_{1}$} & $\mathbf{D}_{1}$ & 113.0 & 18.33 & 57.33 & 41.67 & 21.67 & 1873.33 & 7493.3 & 9366.7 & 0.89 & 8.90 \\
\hline & & $\mathrm{D}_{2}$ & 119.0 & 19.33 & 54.33 & 39.33 & 21.33 & 2073.33 & 8340.0 & 10413.0 & 0.99 & 9.20 \\
\hline & & $\mathrm{D}_{3}$ & 119.3 & 19.67 & 48.67 & 35.33 & 20.33 & 2093.33 & 8383.3 & 10476.7 & 1.00 & 9.35 \\
\hline & \multirow{3}{*}{$\mathbf{N}_{2}$} & $\mathbf{D}_{1}$ & 116.7 & 19.33 & 57.00 & 41.67 & 23.33 & 2080.00 & 8100.0 & 10180.0 & 0.99 & 9.55 \\
\hline & & $\mathrm{D}_{2}$ & 119.3 & 20.00 & 55.33 & 40.33 & 21.67 & 2233.33 & 8500.0 & 10733.3 & 1.06 & 9.68 \\
\hline & & $\mathrm{D}_{3}$ & 123.7 & 20.33 & 49.33 & 36.00 & 20.67 & 2233.33 & 9166.7 & 11500.0 & 1.11 & 9.74 \\
\hline & \multirow{4}{*}{$\mathrm{N}_{3}$} & $\mathrm{D}_{1}$ & 117.3 & 19.00 & 55.00 & 40.00 & 23.33 & 2106.67 & 8300.0 & 10406.7 & 1.00 & 9.64 \\
\hline & & $\mathrm{D}_{2}$ & 119.0 & 18.67 & 52.33 & 38.00 & 23.00 & 2180.00 & 8510.0 & 10690.0 & 1.04 & 9.89 \\
\hline & & $\mathrm{D}_{3}$ & 115.0 & 17.67 & 48.00 & 35.00 & 21.00 & 2206.67 & 8633.3 & 10840.0 & 1.05 & 10.10 \\
\hline & & $\mathrm{D}_{1}$ & 115.0 & 18.67 & 61.33 & 44.67 & 22.33 & 2060.00 & 8246.7 & 10306.7 & 0.82 & 8.71 \\
\hline \multirow{8}{*}{$I_{2}$} & \multirow{2}{*}{$\mathrm{N}_{1}$} & $\mathbf{D}_{2}$ & 120.3 & 21.00 & 57.67 & 41.67 & 23.33 & 2313.33 & 9250.0 & 11563.3 & 0.92 & 8.79 \\
\hline & & $\mathrm{D}_{3}$ & 124.7 & 21.67 & 49.33 & 36.00 & 23.00 & 2393.33 & 9500.0 & 11893.3 & 0.95 & 8.89 \\
\hline & \multirow{3}{*}{$\mathrm{N}_{2}$} & $\mathbf{D}_{1}$ & 119.3 & 20.33 & 62.67 & 45.67 & 24.33 & 2213.33 & 8726.7 & 10940.0 & 0.88 & 8.87 \\
\hline & & $\mathrm{D}_{2}$ & 123.3 & 22.33 & 62.00 & 45.00 & 23.33 & 2466.67 & 9766.7 & 12233.3 & 0.98 & 9.05 \\
\hline & & $\mathrm{D}_{3}$ & 127.3 & 22.00 & 59.00 & 43.00 & 22.67 & 2546.67 & 10093.3 & 12640.0 & 1.01 & 9.21 \\
\hline & \multirow{3}{*}{$\mathrm{N}_{3}$} & $\mathrm{D}_{1}$ & 121.0 & 20.67 & 64.00 & 46.67 & 25.22 & 2306.67 & 9100.0 & 11406.7 & 0.92 & 9.29 \\
\hline & & $\mathbf{D}_{2}$ & 129.3 & 22.00 & 60.67 & 44.33 & 25.11 & 2526.67 & 10050.0 & 12576.7 & 1.00 & 9.37 \\
\hline & & $\mathrm{D}_{3}$ & 130.3 & 22.67 & 58.33 & 42.33 & 25.00 & 2596.67 & 10333.3 & 12930.0 & 1.03 & 9.55 \\
\hline \multirow{10}{*}{$\mathbf{I}_{3}$} & \multirow{3}{*}{$\mathbf{N}_{1}$} & $\mathrm{D}_{1}$ & 116.3 & 20.00 & 62.67 & 45.67 & 22.33 & 2113.33 & 8266.7 & 10380.0 & 0.72 & 8.59 \\
\hline & & $\mathrm{D}_{2}$ & 118.7 & 20.33 & 59.00 & 43.00 & 22.33 & 2376.67 & 9460.0 & 11836.7 & 0.81 & 8.63 \\
\hline & & $\mathrm{D}_{3}$ & 123.7 & 22.67 & 54.00 & 39.33 & 21.67 & 2433.33 & 9700.0 & 12133.3 & 0.83 & 8.68 \\
\hline & \multirow{3}{*}{$\mathbf{N}_{2}$} & $\mathrm{D}_{1}$ & 123.0 & 20.67 & 65.33 & 47.33 & 22.67 & 2286.67 & 9050.0 & 11336.7 & 0.78 & 8.58 \\
\hline & & $\mathrm{D}_{2}$ & 128.0 & 22.00 & 60.67 & 44.33 & 23.33 & 2380.00 & 9510.0 & 11890.0 & 0.81 & 8.69 \\
\hline & & $\mathrm{D}_{3}$ & 134.0 & 23.00 & 57.33 & 42.00 & 24.33 & 2653.33 & 10226.7 & 12880.0 & 0.90 & 8.73 \\
\hline & \multirow{3}{*}{$\mathrm{N}_{3}$} & $\mathrm{D}_{1}$ & 129.3 & 20.67 & 66.67 & 48.67 & 24.67 & 2360.00 & 9293.3 & 11653.3 & 0.80 & 8.77 \\
\hline & & $\mathrm{D}_{2}$ & 132.0 & 23.33 & 62.33 & 45.33 & 24.67 & 2673.33 & 10493.3 & 13166.7 & 0.91 & 8.78 \\
\hline & & $\mathrm{D}_{3}$ & 140.7 & 25.33 & 59.33 & 43.00 & 25.33 & 2703.33 & 10700.0 & 13403.3 & 0.92 & 8.90 \\
\hline & \multicolumn{2}{|c|}{$\operatorname{LSD}(0.05)$} & NS & 1.34 & 1.68 & 1.34 & 1.17 & $\$ 1.62$ & 204.8 & 299.0 & 0.03 & 0.11 \\
\hline
\end{tabular}

$\mathrm{I}_{1}: 5 \mathrm{~mm} / \mathrm{fed} /$ day, $\mathrm{I}_{2}: 6 \mathrm{~mm} / \mathrm{fed} /$ day, $\mathrm{I}_{3}: 7 \mathrm{~mm} / \mathrm{fed} /$ day, $\mathrm{N}_{1}: 60 \mathrm{~kg} \mathrm{~N} / \mathrm{fed}, \mathrm{N}_{2}: 80 \mathrm{~kg} \mathrm{~N} / \mathrm{fed}$, $\mathrm{N}_{3}: 100 \mathrm{~kg} \mathrm{~N} /$ fed, $\mathrm{D}_{1}: 17500$ plant/fed, $\mathrm{D}_{2}: 23333$ plant/fed, $\mathrm{D}_{3}: 35000$ plant/fed, WUE: Water Use Efficiency, LSD: Least Significant Difference

Egyptian J. Desert Res., 65, No. 1, 11-30 (2015) 
Table (8). Effect of irrigation treatments, nitrogen fertilizer and plant density interaction on grain sorghum yield and its components, WUE and protein percentage (2011 season).

\begin{tabular}{|c|c|c|c|c|c|c|c|c|c|c|c|c|}
\hline 1 & $\mathbf{N}$ & D & $\begin{array}{c}\text { Plant } \\
\text { height } \\
\text { (cm) }\end{array}$ & $\begin{array}{c}\text { Head } \\
\text { length } \\
(\mathrm{cm})\end{array}$ & $\begin{array}{c}\text { Head } \\
\text { weight/ } \\
\text { plant } \\
(\mathrm{g})\end{array}$ & $\begin{array}{l}\text { Weight } \\
\text { of grains/ } \\
\text { head } \\
\text { (g) }\end{array}$ & $\begin{array}{l}\text { Seed index } \\
\text { (g) }\end{array}$ & $\begin{array}{l}\text { Grain yield } \\
(\mathrm{kg} / \mathrm{fed})\end{array}$ & $\begin{array}{l}\text { Straw yield } \\
(\mathrm{kg} / \mathrm{fed})\end{array}$ & $\begin{array}{c}\text { Biological } \\
\text { yield } \\
\text { (kg/fed) }\end{array}$ & $\underset{\left(\mathrm{kg} / \mathrm{m}^{3}\right)}{\mathbf{W U E}}$ & $\begin{array}{c}\text { Protein } \\
(\%)\end{array}$ \\
\hline \multirow{9}{*}{$\mathbf{I}_{1}$} & \multirow{3}{*}{$N_{1}$} & $\mathrm{D}_{1}$ & 112.0 & 18.00 & 61.00 & 43.33 & 22.67 & 1906.67 & 7293.3 & 9200.0 & 0.91 & 8.70 \\
\hline & & $\mathbf{D}_{2}$ & 115.0 & 18.33 & 52.00 & 37,00 & 22.33 & 2066.67 & 7476.7 & 9543.3 & 0.98 & 8.74 \\
\hline & & $\mathbf{D}_{3}$ & 116.3 & 19.33 & 46.00 & 36.33 & 20.67 & 2080.00 & 7606.7 & 9686.7 & 0.99 & 8.66 \\
\hline & \multirow{3}{*}{$\mathbf{N}_{2}$} & $\mathbf{D}_{1}$ & 116.3 & 18.67 & 61.67 & 43.33 & 21.67 & 2026.67 & 7700.0 & 9726.7 & 0.97 & 8.90 \\
\hline & & $\mathbf{D}_{2}$ & 115.3 & 19.00 & 58.33 & 40.33 & 21.33 & 2153.33 & 7916.7 & 10070.0 & 1.03 & 8.82 \\
\hline & & $\mathrm{D}_{3}$ & 117.3 & 19.00 & 48.33 & 36.67 & 21.67 & 2273.33 & 8180.0 & 10453.3 & 1.08 & 9.10 \\
\hline & \multirow{3}{*}{$\mathrm{N}_{3}$} & $\mathbf{D}_{1}$ & 113.3 & 18.00 & 61.00 & 42.00 & 22.33 & 2053.33 & 8116.7 & 10170.0 & 0.98 & 9.34 \\
\hline & & $\mathbf{D}_{2}$ & 115.3 & 17.33 & 57.67 & 40.00 & 21.33 & 2133.33 & 8233.3 & 10366.7 & 1.02 & 9.44 \\
\hline & & $\mathbf{D}_{3}$ & 112.3 & 16.33 & 51.00 & 34.33 & 20.33 & 2233.33 & 8400.0 & 10633.3 & 1.06 & 9.46 \\
\hline \multirow{9}{*}{$\mathbf{I}_{2}$} & \multirow{3}{*}{$\mathbf{N}_{1}$} & $\mathbf{D}_{1}$ & 117.0 & 19.67 & 62.33 & 44.00 & 22.33 & 1900.00 & 7400.0 & 9300.0 & 0.75 & 8.58 \\
\hline & & $\mathbf{D}_{2}$ & 119.7 & 20.33 & 58.67 & 42.67 & 22.33 & 2013.33 & 7566.7 & 9580.0 & 0.80 & 8.71 \\
\hline & & $\mathbf{D}_{3}$ & 122.0 & 21.00 & 48.33 & 34.67 & 21.33 & 2126.67 & 8106.7 & 10233.3 & 0.84 & 8.74 \\
\hline & \multirow{3}{*}{$\mathbf{N}_{2}$} & $\mathbf{D}_{1}$ & 118.7 & 20.67 & 66.00 & 46.67 & 24.62 & 2000.00 & 7506.7 & 9506.7 & 0.79 & 8.74 \\
\hline & & $\mathbf{D}_{2}$ & 121.7 & 21.67 & 62.00 & 44.67 & 23.33 & 2163.33 & 8350.0 & 10513.3 & 0.86 & 8.78 \\
\hline & & $\mathbf{D}_{3}$ & 129.0 & 22.67 & 58.33 & 41.67 & 22.67 & 2213.33 & 8750.0 & 10963.3 & 0.88 & 8.88 \\
\hline & \multirow{3}{*}{$\mathrm{N}_{3}$} & $\mathbf{D}_{1}$ & 119.0 & 20.67 & 65.33 & 45.67 & 24.64 & 2083.33 & 8116.7 & 10200.0 & 0.83 & 9.01 \\
\hline & & $\mathbf{D}_{2}$ & 126.0 & 22.00 & 62.67 & 43.00 & 24.00 & 2226.67 & 8956.7 & 11183.3 & 0.88 & 9.13 \\
\hline & & $\mathrm{D}_{3}$ & 126.7 & 22.33 & 55.00 & 38.00 & 23.00 & 2316.67 & 9213.3 & 11530.0 & 0.92 & 9.21 \\
\hline \multirow{9}{*}{$\mathbf{I}_{3}$} & \multirow{3}{*}{$\mathbf{N}_{1}$} & $\mathbf{D}_{1}$ & 118.0 & 19.33 & 63.00 & 45.33 & 22.00 & 1960.00 & 7716.7 & 9676.7 & 0.67 & 8.49 \\
\hline & & $\mathbf{D}_{2}$ & 122.7 & 21.33 & 59.33 & 42.33 & 22.67 & 2090.00 & 8080.0 & 10170.0 & 0.71 & 8.51 \\
\hline & & $\mathbf{D}_{3}$ & 124.0 & 22.00 & 49.33 & 36.33 & 22.33 & 2160.00 & 8233.3 & 10393.3 & 0.73 & 8.52 \\
\hline & \multirow{3}{*}{$\mathrm{N}_{2}$} & $\mathbf{D}_{1}$ & 125.7 & 20.33 & 69.33 & 47.33 & 23.00 & 2113.33 & 8116,7 & 10230.0 & 0.72 & 8.50 \\
\hline & & $\mathbf{D}_{2}$ & 128.7 & 22.00 & 63.33 & 44.67 & 24.33 & 2226.67 & 8533.3 & 10760.0 & 0.76 & 8.56 \\
\hline & & $\mathbf{D}_{3}$ & 132.0 & 23.00 & 56.00 & 40.00 & 23.00 & 2440.00 & 8800.0 & 11240.0 & 0.83 & 8.62 \\
\hline & \multirow{3}{*}{$\mathbf{N}_{3}$} & $\mathbf{D}_{1}$ & 125.7 & 22.33 & 72.33 & 52.67 & 24.67 & 2186.67 & 8053.3 & 10240.0 & 0.74 & 8.72 \\
\hline & & $\mathbf{D}_{2}$ & 134.0 & 23.33 & 66.00 & 47.00 & 23.67 & 2360.00 & 9000.0 & 11360.0 & 0.80 & 8.74 \\
\hline & & $\mathbf{D}_{3}$ & 135.7 & 23.67 & 60.33 & 43.33 & 22.67 & 2513.33 & 9866.7 & 12380.0 & 0.85 & 8.82 \\
\hline \multicolumn{3}{|c|}{ LSD $(0.05)$} & NS & $\mathrm{NS}$ & 3.19 & $\mathrm{NS}$ & NS & 49.40 & 131.44 & 179.8 & NS & $\mathrm{NS}$ \\
\hline
\end{tabular}

\section{CONCLUSION}

It could be concluded that under the conditions of New Valley region, application of $7 \mathrm{~mm} / \mathrm{fed}\left(2940 \mathrm{~m}^{3} / \mathrm{fed}\right) \mathrm{x}$ adding $100 \mathrm{~kg} \mathrm{~N} / \mathrm{fed} \mathrm{x}$ plant density of 35000 plant/fed could be recommended for good use of environmental resources and maximizing grain sorghum productivity.

Egyptian J. Desert Res., 65, No. 1, 11-30 (2015) 


\section{REFERENCES}

Abdalla, F.H., B.R. Bakheit, M.M. Saadalla and T.A. Ahmed (1994). Genotypic response and variance components in grain sorghum under different water regimes. Assiut J. Agric. Sci., 25 (2): 13-24.

Abdel-Motagally, F.M.F. (2010). Evaluation of water use WUE under different water regimes in grain sorghum (Sorghum bicolor L. Monech). World J. of Agric. Sci., 6 (5): 499-505.

Abou-Amer, A.I. and K.Z. Kewan (2014). Effect of NP fertilization levels on sorghum (Sorghum bicolor L.) yield and fodder quality for animals. Alex .J. Agric. Res., 59 (1): 51-59.

Afshar, R.K., M.A. Jovini, M.R. Chaichi and M. Hashemi (2014). Grain sorghum response to arbuscular mycorrhiza and phosphorus fertilizer under deficit irrigation. American Society of Agronomy, 106 (4): 1212-1218.

Andrade, F.H., P. Calvino, A. Cirilo and P. Barbieri (2002). Yield responses to narrow rows depend on increased radiation interception. Agronomy Journal, 94 (5): 975-980.

A.O.A.C. (1995). In "Official Methods of Analysis". 16 $6^{\text {th }}$ Association of Official Analytical Chemists, Washington, DC, USA.

Asghari, E., K. Razmjoo and M.M. Tehrani (2006). Effect of nitrogen rates on yield and yield components and grain protein of grain sorghum (Sorghum bicolor). J. Agric. Sci. Natur. Resour., 13 (1): 49-57.

Beheshti, A.R. and B. Fard (2010). Dry matter accumulation and remobilization in grain sorghum genotypes (Sorghum bicolor L. Monech) under drought stress. Australian J. crop Sci., 4 (3): 185189.

Blum, A. (2004). In "Sorghum Physiology". (Nguyen, H.T., Bluma eds.). Physiology and Biotechnology Integration for Plant Breeding. Marcel Dekker, New York.

Buah, S.S.J. and S. Mwinkaara (2009). Response of sorghum to nitrogen fertilizer and plant density in the guina Savana zone. Agron. J., 8 (3): 124-130.

Doorenbos, J., W.O. Pruitt, A. Aboukhaled, J. Damagnez, N.G. Dastane, C. Van Den Berg, P.E. Rijtema, O.M. Ashford, and M. Frere (1977). Guidelines for predicting crop water requirements, irrigation and drainage FAO, Rome, 24: 35-95.

El-Sarag, I. Eman and G.M. Abu Hashem (2009). Effect of irrigation intervals and nitrogen rates on forage sorghum under North Sinai conditions. Zagazig J. Agric. Res., 36 (1): 19-39.

Everaarts, A.P. (1993). Effects of competition with weeds on the growth, development and yield of sorghum. J. of Agric. Sci., 120 (2): 187196. 
Fernandez, C.J., D.D. Fromme and W.J. Grichar (2012). Grain sorghum response to row spacing and plant populations in the Texas Coastal Bend Region. International J. of Agron., 2012 : 1-6.

Gomez, K.A. and A.A. Gomez (1984). In "Statistical Procedure for Agriculture Research". An International Rice Research Institute Book John Willey and Sons, Inc., New York.

Henke, J., G. Breustedt, K. Sieling and H. Kage (2007). Impact of uncertainty on the optimum nitrogen fertilization rate and agronomic, ecological and economic factors in an oilseed rape based crop rotation. J. of Agric. Sci. Cambridge, 5 (4): 55-68.

Jahanzad, M., M. Jorat, H. Moghadam, A. Sadeghpour, M. R. Chaichi and M. Dashtaki (2013). Response of a new and a commonly grown forage sorghum cultivar to limited irrigation and planting density. Agricultural Water Management, 117: 62-69.

Javadi, H., M.H. Rashed Mohasel, G. Zamani, A. Azari Nasrabad and G. Mousavi (2005). Study on effect of plant density on yield, yield components and protein percentage of four grain sorghum cultivars. Iranian J. of Agricultural researches, 3(2): 233-243.

Keller, J. and R.D. Bliesner (1990). In "Trickle Irrigation", Part III in Sprinkler and Trickle irrigation, Van N. Reinhold. New York, pp. $28-477$.

Kidambi, S.P., D.R. Krieg, D.T. Rosenow (1990). Genetic variation for gas exchange rates in grain sorghum. Plant Physiol, 92: 1211-1214.

Lak, S., A. Naderi, S.A.A. Siadat, A. Aynehband, G. Noormohammadi and S.H. Mousavi (2006). Effect of different irrigation and plant densities levels on yield, yield components and assimilate remobilization of grain maize under climatic conditions of Khuzestan. Iran. J. of Agric. and Natural Resources Sciences, 10 (43): 92-101.

Mahama, G.Y., P.V. Vara Prasad, D.B. Mengel and T.T. Tesso (2014). Influence of nitrogen fertilizer on growth and yield of grain sorghum hybrids and inbred lines. American Society of Agronomy, 106 (5): 1623-1630.

Mastrorilli, M. I., N. Katerji and G. Rana (1995). Water WUE and stress on grain sorghum at different reproductive stages. Agric. Water Management, 28: 23-24.

Mousavi, S.G.R., M.J. Seghatoleslami and R. Arefi (2012). Effect of N fertilization and plant density on yield and yield components of grain sorghum under climatic conditions of Sistan, Iran. Plant Ecophysiology, 4: 141-149.

Munamava, M. and I. Riddoch (2001). Response of three sorghum (Sorghum bicolor (L.) Moench) varieties to soil moisture stress at different developmental stages. South African J. of Plant Soil, 18 (2):75-79.

Egyptian J. Desert Res., 65, No. 1, 11-30 (2015) 
Pene, C.B.G. and G.K. Edi (1996). In "Sugarcane Yield Response to Deficit Irrigation at Two Growth Stages". Nuclear Techniques to Assess Irrigation Schedules for Field Crops. IAEA, TECDOC 888, pp. 115129 , Vienna.

Sanabria, J.R., J.F. Stone and D.L. Weeks (1995). Stomatal response to high evaporative demand in irrigated grain sorghum in narrow and wide row spacing. Agronomy Journal, 87 (5): 1010-1017.

Sher, A., L. Barbanti, M. Ansar and M.A. Malik (2013). Growth response and plant water status in forage sorghum (Sorghum bicolor (L.) Moench) cultivars subjected to decreasing levels of soil moisture. Australian J. of Crop Sci., 7 (6): 801-808.

Soleymani, A., M.H. Shahrajabian and Lila Naranjani (2011). The effect of plant density and nitrogen fertilization on yield, yield components and grain protein of grain sorghum. Journal of Food, Agriculture \& Environment, 9 (3\&4): 244-246.

Spiertz, J.H.J. (2010). Nitrogen, sustainable agriculture and food security. A review of Agronomy sustainable Development, 30: 43-55.

Steiner, J.L. (1986). Dryland grain sorghum water use, light interception and growth responses to planting geometry. Agronomy J., 78: 720-726.

Swati, M.S., H. Rahman and J. Afsar (1985). Response of wheat cultivars to different levels of water stress. Sarhad J. Agric., 1: 284-304.

Thelen, K.D. (2006). Interaction between row spacing and yield: why it works. Crop Management.

Walker, R.H. and G.A. Buchanan (1982). Crop manipulation in integrated weed management systems. Weed Sci., 30: 17-24.

Zand, N. and M.R. Shakiba (2013). Effect of plant density and nitrogen fertilizer on some attribute of grain sorghum (Sorghum bicolor (L.) Moench). International journal of Advanced Biological and Biomedical Research, 1 (12): 1577-1582.

Zand, N., M.R. Shakiba, M.M. Vahed and A.D.M. Nasab (2014). Response of sorghum to nitrogen fertilizer at different plant densities. International. J. of Farming and Allied Sci., 3 (1):71-74. 
إستجابة الذرة الرفيعة لماء الري، النيتروجين والكثافة النباتية تحت الترات ظروف الوادي الجديد، مصر الترو

\author{
قسم الإنتاج النباتي، مركز بحوث الصحر اء، المطرية، القاهرة، مصر
}

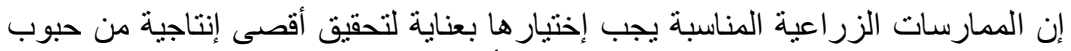

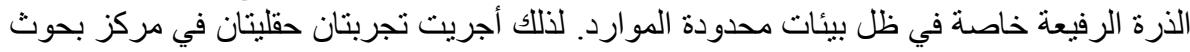

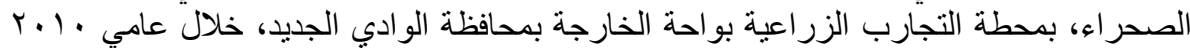

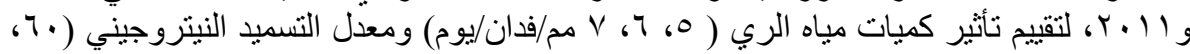

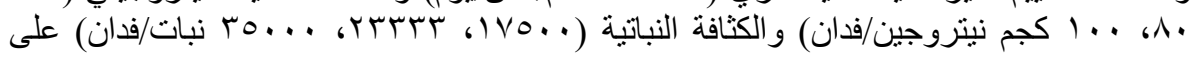

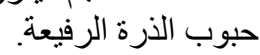

أظهرت النتائج أن الري بمعدل V مم/فدان/يوم كان المعاملة الفعالة لزيادة إرتفاع النبات،

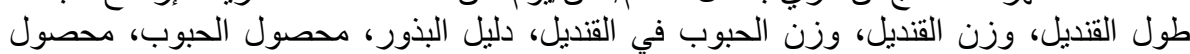

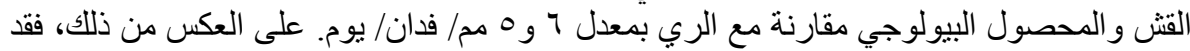

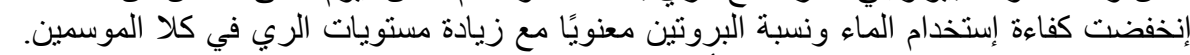

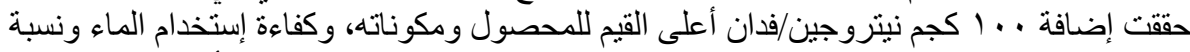

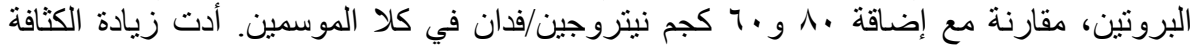

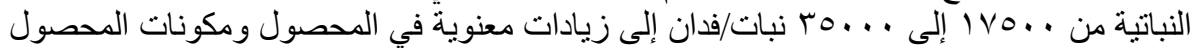

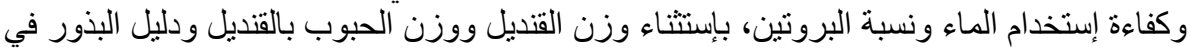

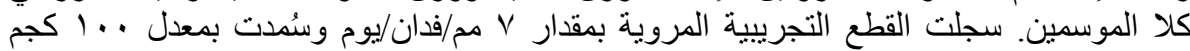

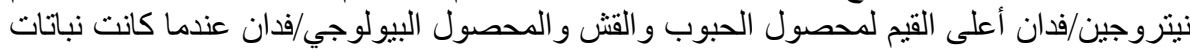
الذرة الرفيعة عند الكثافة النباتية المرتفعة ( (... ب نبات/فدان).

Egyptian J. Desert Res., 65, No. 1, 11-30 (2015) 